\title{
POROSITY DETERMINATION WITH HELIUM PYCNOMETRY AS A METHOD TO CHARACTERIZE WATERLOGGED WOODS AND THE EFFICACY OF THE CONSERVATION TREATMENTS*
}

\author{
I. D. DONATO and G. LAZZARA \\ Dipartimento di Chimica 'Stanislao Cannizzaro', Università degli Studi di Palermo, Viale delle Scienze—Edificio 17, \\ 90128 Palermo, Italy
}

\begin{abstract}
The helium pycnometer allows us to measure the cell-wall density of dry woods and the basic density of wood samples soaked with water and/or a consolidant solution if a non-volatile solvent is used. These parameters were correlated to the porosity, which for degraded waterlogged wood is related to the maximum water content. Moreover, this has revealed the possibility of investigating, by means of accurate cell-wall density determination, the efficacy of several consolidants in the treatment of waterlogged woods.
\end{abstract}

KEYWORDS: HELIUM PYCNOMETRY, POROSITY, DENSITY, WATERLOGGED WOOD, CONSOLIDATION

\section{INTRODUCTION}

Many properties of archaeological wood, particularly those involving deterioration, sorption, penetrability, swelling and strain-related phenomena, are probably dependent on the porosity of the wood, which, in turn, depends on cell-wall and basic densities (Capretti et al. 2008). Thus, accurate measurements of these physical parameters are essential for a correct determination of such properties. Several conventional methods have been successfully applied for determination of the physical and chemical properties of waterlogged archaeological woods (Capretti et al. 2008; Pizzo et al. 2010). The concept of density is very simple, and the mass and volume of a body would seem to be among the easiest physical parameters to measure. Actually, for a porous, hygroscopic, polymeric material, the measurement of the volume is extremely controversial. This is particularly true in the determination of basic and cell-wall densities of wood. For determination of the basic density, the volume is measured by either of two techniques. The volume of samples with a proper geometrical shape is obtained from the characteristic dimensions measured by means of a calliper, whereas for samples with an irregular shape, the volume is obtained by means of a Regnault pycnometer, employing mercury as a reference liquid. The measure of the cell-wall volume in order to determine the cell-wall density is more difficult.

Gas pycnometry, based on the Boyle-Mariotte law of the volume-pressure relationship, is an effective tool to determine the volume of porous materials because it does not possess the limitations of other testing methods (Tamari 2004), such as the problem of air entrapment. In gas pycnometry the main approximation in the estimation of the sample volume is the non-ideal gas behaviour and its adsorption on to the solid material. Nevertheless, experimental results (Weber and Bastick 1968) and modern simulations of gas adsorption on solids (Neimark and Ravikovitch 1997; Talu and Myers 2001) have demonstrated that helium can reasonably be considered as an ideal and non-adsorbing gas at room temperature $(300 \mathrm{~K})$ and low pressure $(<0.5 \mathrm{MPa})$. A gas

*Received 12 July 2011; accepted 7 November 2011

(C) University of Oxford, 2012 
pycnometer, using pure helium, was employed in this work to measure the cell-wall density of degraded waterlogged wood after dehydration, and of wood finds preserved with enforcing materials after exsiccation. Moreover, helium pycnometry could be used to measure the basic density when a wood sample soaked with water and/or a consolidant solution of a non-volatile solvent is used.

The primary purpose of this study was to:

(a) correlate the Maximum Water Content (MWC\%) (Florian 1990, 8) with the porosity of degraded waterlogged wood;

(b) test the modifications of the cell-wall density of softwood and hardwood dehydrated archaeological finds; and

(c) study the effects on the porosity of several chemicals used as strengtheners for degraded woods.

\section{EXPERIMENTAL}

\section{Materials}

Poly(ethylene)glycols (PEG 4000, PEG 1500 and PEG 600), hydroxypropylcellulose (Klucel, $M_{\mathrm{w}}=80 \mathrm{kDa}$ ) and $\alpha$-D-glucopyranosyl- $\alpha$-D-glucopyranoside (TREA) are from Sigma. The acetone was a J. T. Baker product. Colophony (from Phase) is a complex mixture essentially composed of isomers of abietic acid (90\%) and the corresponding esters, aldehydes and alcohols $(10 \%)$. Rosin $100^{\circledR}$ (from Bresciani s.r.l.) is a chemically modified colophony (stabilized ester of pentaerythritol). Vinavil $8020 \mathrm{~S}^{\circledR}$ is a commercial copolymer (vinyl acetate and vinyl versate) from Mapei SpA. The densities of the pristine consolidants and their solutions used for the consolidation treatments are given in Table 1.

\section{Wood samples and characterization}

Wood samples were collected from findings related to the ancient vegetation coeval with the ancient ships of Pisa (Italy) from that archaeological site. They are dated from the seventh century

Table 1 Densities of dried consolidants and their solutions at $25^{\circ} \mathrm{C}$

\begin{tabular}{lcc}
\hline \hline & $\begin{array}{c}\text { Density of solution } \\
\left(\mathrm{g} \mathrm{cm}^{-3}\right)\end{array}$ & $\begin{array}{c}\text { Density of dried consolidant } \\
\left(\mathrm{g} \mathrm{cm}^{-3}\right)\end{array}$ \\
\hline $20 \%$ PEG4000 + 2\% TREA in water & 1.042 & $1.20,{ }^{*} 1.58 \dagger$ \\
$20 \%$ PEG1500 + 2\% TREA in water & 1.064 & $1.20,{ }^{*} 1.58 \dagger$ \\
$20 \%$ PEG600 + 2\% TREA in water & 1.044 & $1.20 *{ }^{*} 1.58 \dagger$ \\
$7 \%$ Klucel in water & $1.009+$ & 1.27 \\
$60 \%$ colophony in acetone & 0.970 & 1.08 \\
$60 \%$ Rosin 100 in acetone & 0.957 & 1.07 \\
$7 \%$ Vinavil $8020 \mathrm{~S}$ in acetone & 0.817 & 0.93 \\
\hline \hline
\end{tabular}

*PEG.

$\dagger$ TREA.

$\ddagger$ The temperature is $30^{\circ} \mathrm{C}$. 
BC to the second century AD (Giachi et al. 2011). Samples of waterlogged wood were characterized according to the procedure of the Italian standard UNI 11205:2007 (see UNI 2007). The identification of wood taxa was done by means of optical microscopy on thin sections along the three characteristic directions of wood; from this analysis and the comparison with the taxonomic tables UNI 11118:2004 (see UNI 2004), the wood samples were classified as softwood (Larix decidua Mill., Pinus nigra Arnold and Pinus pinaster Aiton) and hardwood (Arbutus unedo L., Ulmus cf. minor, Fagus sylvatica L. and Quercus sp. caducifolia).

\section{Wood treatments}

The wood desalination was performed by washing samples with deionized water at $25^{\circ} \mathrm{C}$; the procedure was halted when the conductivity was $\leq 10 \mu \mathrm{S} \mathrm{cm}^{-1}$ :

(a) Waterlogged archaeological wood was consolidated after desalination by impregnation carried out by immersing the samples in a solution of water-soluble polymers (PEGs + TREA or Klucel). Refractive index $\left(n_{\mathrm{D}}\right)$ measurements were utilized to follow the evolution of the process of impregnation. The impregnation was considered complete when the refractive index of the solutions in which the sample was immersed approached the concentration value of the impregnating mixture before its use, within the limits of the measurement error. Drying after treatment was carried out by freeze-drying $\left(-45^{\circ} \mathrm{C}, 10^{-4} \mathrm{~atm}\right)$. The latter operation was performed by using a Heto FD 2.5 freeze-dryer.

(b) Different samples of waterlogged archaeological wood were consolidated by immersion in acetone solutions of: (60 wt \%) colophony, (60 wt \%) Rosin 100 and (7 wt \%) Vinavil 8020S. In this case, the impregnation water was replaced by acetone, and the refractive index $\left(n_{\mathrm{D}}\right)$ measurements were used to follow the kinetics of the process. Finally, acetone-filled samples were immersed in the consolidating solutions. The diffusion of these solutions into wood was followed by measuring the variation of the consolidant concentration with time through viscosity measurements. Flow-time was measured at constant temperature by means of a Ubbelohde-type capillary micro-viscosimeter, equipped with an optical sensor and an AVS 440 automatic unit from Schott-Geräte. A second impregnation step was carried out after the first one, and in some cases the temperature was increased in order to speed up the process.

After treatment, each sample was placed into a box at room temperature $\left(25^{\circ} \mathrm{C}\right.$ and $\left.1 \mathrm{~atm}\right)$ to slowly remove the acetone; the box was opened periodically to let the acetone vapours out (Giachi et al. 2010).

\section{Methods}

The Accupyc 1330 Micromeritics gas pycnometer, which used 99.995\% pure helium, was employed to determine the volume of the samples by measuring the pressure change of helium in a calibrated volume. The apparatus had a $10 \mathrm{~cm}^{3}$ cell, well suited for the small available quantities of many of the studied materials. Standards for the volume calibration (balls purchased from Micromeritics, $V_{\text {cal }}=6.371684 \mathrm{~cm}^{3}$ ) were used at $25^{\circ} \mathrm{C}$.

The experiments were performed by using the cell with a $75 \%$ filling ratio. The results showed that density values and standard deviations (corresponding to the 10 repetitions for each analysis) decreased with the number of purges. The repeatability of the technique was investigated by conducting three independent analyses on the same sample. The measurements were performed on the same day with a new sample for each analysis, because of the possible evolution of the product during purges and measurements. The pressure was considered constant if the rate was 
$0.34 \mathrm{mbar}^{-1} \mathrm{~min}^{-1}$. The variation in the pycnometer density, due to the operating parameters, can affect the accuracy of the result up to $0.01 \mathrm{~g} \mathrm{~cm}^{-3}$. Before each cell-wall density measurement, the wood samples (dried at $105^{\circ} \mathrm{C}$ and freeze-dried, or air dried at $25^{\circ} \mathrm{C}$ ) were kept in a desiccator for $2 \mathrm{~h}$ under vacuum.

\section{RESULTS AND DISCUSSION}

\section{Waterlogged degraded archaeological wood}

Within the field of cultural heritage, wood plays a relevant role. These finds can survive better in wet environments where microbial and fungal activities are limited, as in the case of underwater shipwrecks. In such environments, anaerobic bacteria are primarily responsible for the depletion of wood (Björdal and Nilsson 2000, 2008). Waterlogged woods are characterized and classified based on physical, chemical and biological parameters, by analysis of the wood structure and by optical and electron microscopy. The water content and density are the physical parameters most frequently determined, in order to obtain a rapid classification of decay for waterlogged wood (Florian 1990, 8).

The maximum water content (MWC\%) is determined as follows:

$$
\text { MWC } \%=100 \times(\text { mass of water in wet wood sample }) /(\text { oven-dry mass of wood sample })
$$

The wet wood sample is dried at $(105 \pm 2)^{\circ} \mathrm{C}$ to constant mass (accurate to $0.0001 \mathrm{~g}$ ); the mass of water is determined from the difference in the mass of the sample before and after the drying treatment.

The basic density $\left(d_{\mathrm{b}}\right)$ was calculated from oven-dry mass and water-saturated volume; this method is appropriate for degraded waterlogged woods. The basic density of archaeological wood is constrained between the value for identical sound taxon and zero as the wood approaches total destruction. In other words, the density deviation from the value of sound wood is a measure of the extent of deterioration.

The cell-wall density $\left(d_{\text {cell-wall }}\right)$ was based on oven-dry weight and dry volume, namely the volume occupied by the cell wall. The porosity of wood $(Z \%)$ is related to the cavity volume $\left(V_{\mathrm{c}}\right)$ and to the volume of the water-saturated sample $\left(V_{\text {total }}\right)$. Moreover, $\left(V_{\text {cell-wall }}\right)$ is the volume of the cell wall. The following equations correlate these parameters:

$$
\begin{gathered}
V_{\mathrm{c}}=\left(V_{\text {total }}-V_{\text {cell-wall }}\right) \\
Z \%=100 \times\left(V_{\text {total }}-V_{\text {cell-wall }}\right) / V_{\text {total }}=100 \times\left(1-d_{\mathrm{b}} / d_{\text {cell-wall }}\right)
\end{gathered}
$$

Mercury intrusion porosimetry (MIP) is used, in general, to evaluate the pores' volume and their size distribution. However, this instrument cannot be used for porosity measurement of waterlogged woods, because of the necessary high pressure, which leads to compression of wood and consequently to the collapse of a number of pores or voids. Instead, the accurate determination of the cell-wall density and, therefore, of the porosity is made possible by using the gas pycnometer. At present, the instrument considered to give the closest approximation to the true density of the cell wall is the helium pycnometer. The accuracy is due to the fact that helium penetrates into the smallest pores and crevices, approaching the real volume. The use of this instrument for cell-wall density determination offers the advantage of being easy to use and 
rapid, especially with a fully automated apparatus. The accuracy and the reproducibility of the technique are sufficient to reveal minute variations.

For each wood sample, MWC $\%, d_{\mathrm{b}}$ and $d_{\text {cell-wall }}$ were determined at $25^{\circ} \mathrm{C}$, and the porosity, $Z \%$, was calculated from the density values shown in equation (3). These quantities are reported in Table 2 . The investigated waterlogged woods are very degraded, as the calculated values of $\mathrm{MWC} \%$ show, in agreement with results from the holocellulose-to-lignin ratio reported elsewhere (Pizzo et al. 2010). The $d_{\mathrm{b}}$ values, experimentally determined by using the helium pycnometer, are related to those of MWC: high water contents are linked to a low basic density of decayed waterlogged woods. The $d_{\text {cell-wall }}$ values for each sample vary. They differ from the literature values for sound woods $\left(d_{\text {cell-wall }}=1.50\right.$ or $\left.1.53 \mathrm{~g} \mathrm{~cm}^{-3}\right)$ and for waterlogged woods $\left(d_{\text {cell-wall }}=1.48 \mathrm{~g} \mathrm{~cm}^{-3}\right)$, as reported by Jensen and Gregory (2006). From a more accurate analysis of the results, it emerges that the taxon and the degree of deterioration can affect the structure of the cell wall; indeed, the $d_{\text {cell-wall }}$ values are in the range from 1.41 to 1.38 and from 1.37 to $1.50 \mathrm{~g} \mathrm{~cm}^{-3}$, for archaeological softwoods and hardwoods, respectively.

The softwoods contain more lignin than hardwoods, and lignin has the lowest specific gravity $\left(1.30 \mathrm{~g} \mathrm{~cm}^{-3}\right)$ compared to cellulose $\left(1.54 \mathrm{~g} \mathrm{~cm}^{-3}\right)$ and hemicellulose $\left(1.53 \mathrm{~g} \mathrm{~cm}^{-3}\right)$ (Pfriem et al. 2009). The $d_{\text {cell-wall }}$ values of waterlogged woods are markedly dependent on the nature of degradation of the cell-wall components. Biological and chemical degradation cause depolymerization of the polysaccharide matrix against a limited degradation of the lignin fraction; this explains why the cell-wall values approach the lignin value upon increasing degradation. A multi-analytical study of degradation of lignin in waterlogged wood reported that lignin from archaeological wood can also be altered, leading to a higher amount of free phenol units compared to lignin from sound wood of the same species taken as a reference (Colombini et al. 2009). A loss of cellulose and hemicellulose and the modified lignin caused the formation of water-filled cavities and resulted in a porous and fragile structure.

Table 2 The taxa and physical characteristics of the waterlogged wood samples

\begin{tabular}{|c|c|c|c|c|}
\hline Taxa & $M W C \%$ & $\begin{array}{c}d_{b} \\
\left(g \mathrm{~cm}^{-3}\right) \\
\sigma \pm 0.01\end{array}$ & $\begin{array}{c}d_{\text {cell wall }} \\
\left(\mathrm{g} \mathrm{cm}^{-3}\right) \\
\sigma \pm 0.01\end{array}$ & $\begin{array}{c}Z \% \\
\sigma \pm 0.1\end{array}$ \\
\hline \multicolumn{5}{|l|}{ Softwood } \\
\hline European larch, Larix decidua Mill. & 546 & 0.16 & 1.40 & 88.7 \\
\hline European larch, Larix decidua Mill. & 505 & 0.18 & 1.41 & 87.2 \\
\hline Stone pine, Pinus pinaster Aiton & 689 & 0.13 & 1.38 & 90.6 \\
\hline Stone pine, Pinus pinaster Aiton & 559 & 0.16 & 1.38 & 88.4 \\
\hline Austrian black pine, Pinus nigra Arnold & 375 & 0.22 & 1.41 & 83.4 \\
\hline Austrian black pine, Pinus nigra Arnold & 390 & 0.22 & 1.39 & 84.2 \\
\hline \multicolumn{5}{|l|}{ Hardwood } \\
\hline Strawberry tree, Arbutus unedo L. & 704 & 0.13 & 1.34 & 90.3 \\
\hline Elm, Ulmus cf. minor & 549 & 0.17 & 1.36 & 87.5 \\
\hline Elm, Ulmus cf. minor & 479 & 0.19 & 1.41 & 86.5 \\
\hline Oak, Quercus sp. caducifolia & 471 & 0.19 & 1.44 & 86.8 \\
\hline European beech, Fagus sylvatica L. & 678 & 0.14 & 1.37 & 89.8 \\
\hline
\end{tabular}


The MWC\% values are strictly correlated with the cavities present in the samples for both the hardwoods and the softwoods. The MWC\% determination based on both gravimetry and thermogravimetry (Donato et al. 2010; Cavallaro et al. 2011a) provides an immediate evaluation of the water content entrapped in the wood cavity and therefore gives insights on the state of degradation of the wood. The porosity values calculated using the helium pycnometer are reliable because helium may easily penetrate even in the smallest cavities of the cell wall. Eventual differences between the porosity values obtained in wet and dry conditions might be ascribed to different structure assumed by the cell wall and different water and helium penetration, which is larger for the inert gas.

The evaluation of porosity is of basic importance, since it is a key parameter in the proper choice of compounds to be used as protective and/or consolidating agents. A progressive substitution of water with suitable strengthening materials can preserve the physical features of archaeological finds. It is also possible to determine the porosity of the treated woods. The Z\% values determined before and after the consolidation treatment are indicative of the effectiveness of the consolidation process.

\section{Waterlogged wood strengtheners}

Treatment with polymers soluble in water Archaeological degraded wood samples were impregnated by immersion in aqueous solutions of mixtures of $20 \%$ PEGs (polyethylene glycol of various molecular weights) and 2\% TREA. Recent studies showed that TREA causes a dramatic decrease of the ordered structure of water molecules in its solutions due to breaking of hydrogen bonds (Gallina et al. 2006), and this was considered to facilitate the removal of water molecules during drying (Italiano 2004). Other specimens from the same degraded waterlogged woods were impregnated with $7 \%$ aqueous Klucel solutions. The Klucel can interact with all the components of wood (cellulose, hemicelluloses and lignin) and can cover the cavities with a protective and stabilizing film. The aqueous Klucel has been used successfully in the strengthening of degraded waterlogged wood (Donato and Agozzino 2004) and for preparing protective films (Cavallaro et al. 2011b).

The mass of the lyophilized samples, and the volumes of impregnated samples, determined with the helium pycnometer, were used to calculate $d_{\mathrm{b}}, d_{\text {cell-wall }}{ }^{*}$ and $Z \%$ of the treated samples. The taxa, MWC $\%, d_{\mathrm{b}}, d_{\text {cell-wall }}{ }^{*}, Z \%$ and its change $(\Delta Z \%)$ before and after the various strengthening treatments are collected in Table 3 . It has to be noted that in the case of consolidated woods, $d_{\text {cell-wall }}$ * refers to the density of the cell wall plus the consolidant encrusting the cell wall. $\Delta Z$ was a minimum for the wood specimens treated with aqueous Klucel solution. For (PEG + TREA)-treated samples, the largest change of porosity was found with PEG 600, followed by PEG 1500 and then PEG 4000, for both the hardwoods and the softwood (Fig. 1). The influence of the PEG's molecular dimensions on the porosity of treated wood samples decreases as the MWC\% increases. The nature of the taxon, MWC\% and the PEG's molecular dimensions are the parameters that drive the entrance of the strengthener into the degraded wood structure. In our case, the diffusion of the consolidant mixture is the relevant process, and therefore the viscosity, the size of the molecules and the amount of water sorbed/bound to the impregnation molecule play a role (Eaton and Hale 1993, 392). The viscosities of the polymer solutions are $4.66 \mathrm{mPa} \mathrm{s}, 2.40 \mathrm{mPa}$ s and $1.63 \mathrm{mPa} \mathrm{s}$, for PEG 4000, PEG 1500 and PEG 600, respectively. Low molecular mass and small steric hindrance polymers can penetrate more easily into the smallest crevices of the cellular structure.

The Klucel solutions, owing to their high viscosity and to the large molecular dimensions of the polymer, diffuse into the cellular structure with difficulty. Comparison of the porosity values 
Table 3 Densities and porosity of waterlogged woods before and after consolidation

\begin{tabular}{|c|c|c|c|c|c|}
\hline Taxa & $M W C \%$ & $\begin{array}{c}d_{\text {cell-wall }}\left(\mathrm{g} \mathrm{cm}^{-3}\right) \\
\sigma \pm 0.01\end{array}$ & $\begin{array}{c}d_{b}\left(\mathrm{~g} \mathrm{~cm}^{-3}\right) \\
\sigma \pm 0.01\end{array}$ & $\begin{array}{c}Z \% \\
\sigma \pm 0.1\end{array}$ & $\Delta Z \%$ \\
\hline \multicolumn{6}{|l|}{ Dried at $105 \pm 2{ }^{\circ} \mathrm{C}$} \\
\hline Oak, Quercus sp. caducifolia & 471 & 1.44 & 0.19 & 86.8 & - \\
\hline Elm, Ulmus cf. minor & 549 & 1.36 & 0.17 & 87.5 & - \\
\hline Stone pine, Pinus pinaster Aiton & 689 & 1.38 & 0.13 & 90.6 & - \\
\hline Strawberry tree, Arbutus unedo L. & 704 & 1.34 & 0.13 & 90.3 & - \\
\hline \multicolumn{6}{|l|}{$20 \%$ PEG $4000+2 \%$ TREA } \\
\hline Oak, Quercus sp. caducifolia & & 1.24 & 0.40 & 67.7 & 19.1 \\
\hline Elm, Ulmus cf. minor & & 1.29 & 0.39 & 69.8 & 17.7 \\
\hline Stone pine, Pinus pinaster Aiton & & 1.30 & 0.39 & 70.0 & 20.6 \\
\hline Strawberry tree, Arbutus unedo L. & & 1.27 & 0.35 & 72.4 & 17.9 \\
\hline \multicolumn{6}{|l|}{$20 \%$ PEG $1500+2 \%$ TREA } \\
\hline Oak, Quercus sp. caducifolia & & 1.26 & 0.50 & 60.3 & 26.5 \\
\hline Elm, Ulmus cf. minor & & 1.34 & 0.41 & 69.4 & 22.6 \\
\hline Stone pine, Pinus pinaster Aiton & & 1.30 & 0.41 & 68.5 & 22.1 \\
\hline Strawberry tree, Arbutus unedo L. & & 1.23 & 0.34 & 72.3 & 17.9 \\
\hline \multicolumn{6}{|l|}{$20 \%$ PEG $600+2 \%$ TREA } \\
\hline Oak, Quercus sp. caducifolia & & 1.27 & 0.57 & 55.1 & 31.7 \\
\hline Elm, Ulmus cf. minor & & 1.31 & 0.41 & 69.0 & 23.0 \\
\hline Stone pine, Pinus pinaster Aiton & & 1.28 & 0.41 & 68.0 & 22.6 \\
\hline Strawberry tree, Arbutus unedo L. & & 1.24 & 0.36 & 71.0 & 19.3 \\
\hline \multicolumn{6}{|l|}{$7 \%$ Klucel } \\
\hline Oak, Quercus sp. caducifolia & & 1.37 & 0.30 & 78.1 & 8.7 \\
\hline Elm, Ulmus cf. minor & & 1.37 & 0.24 & 82.5 & 5.0 \\
\hline Stone pine, Pinus pinaster Aiton & & 1.40 & 0.30 & 78.6 & 12.0 \\
\hline Strawberry tree, Arbutus unedo L. & & 1.41 & 0.20 & 85.8 & 4.5 \\
\hline
\end{tabular}

before and after the treatment with Klucel allowed the evaluation of the performance of the soaking process. The observed small decrease in the porosity may be an indication of the film-forming ability of the polymer on the cell wall. The SEM and TEM images showed that Klucel stabilizes the cellular structures, possibly through the formation of bonds between the cellulose ether and the components of the wooden matrix. Analysis of relaxation curves and imaging proved that water absorption is a reversible process and, as a consequence of all the above, we can affirm that Klucel is a good protective agent (Maccotta et al. 2004).

Treatment with polymers soluble in acetone In Table 4, the taxa, MWC\% and the $d_{\text {cell-wall }}$ values with relative standard deviations are reported for samples of waterlogged woods dried at $(105 \pm 2)^{\circ} \mathrm{C}$, treated with acetone, acetone solution of colophony, Rosin 100 or Vinavil $8020 \mathrm{~S}$ and after acetone evaporation. The data are given in Figure 2 for a better comparison. It was not possible to measure $d_{\mathrm{b}}$ for impregnated samples, because any common method used to determine the volume could not be applied to treated samples. Specifically, it was difficult to obtain a proper sample, so that the volume could not be calculated from external dimensions measured using a calliper. On the other hand, the Regnault pycnometer was not appropriate because of the rather large cavity size, from which $\mathrm{Hg}$ can percolate. Helium pycnometry could not be used for the 


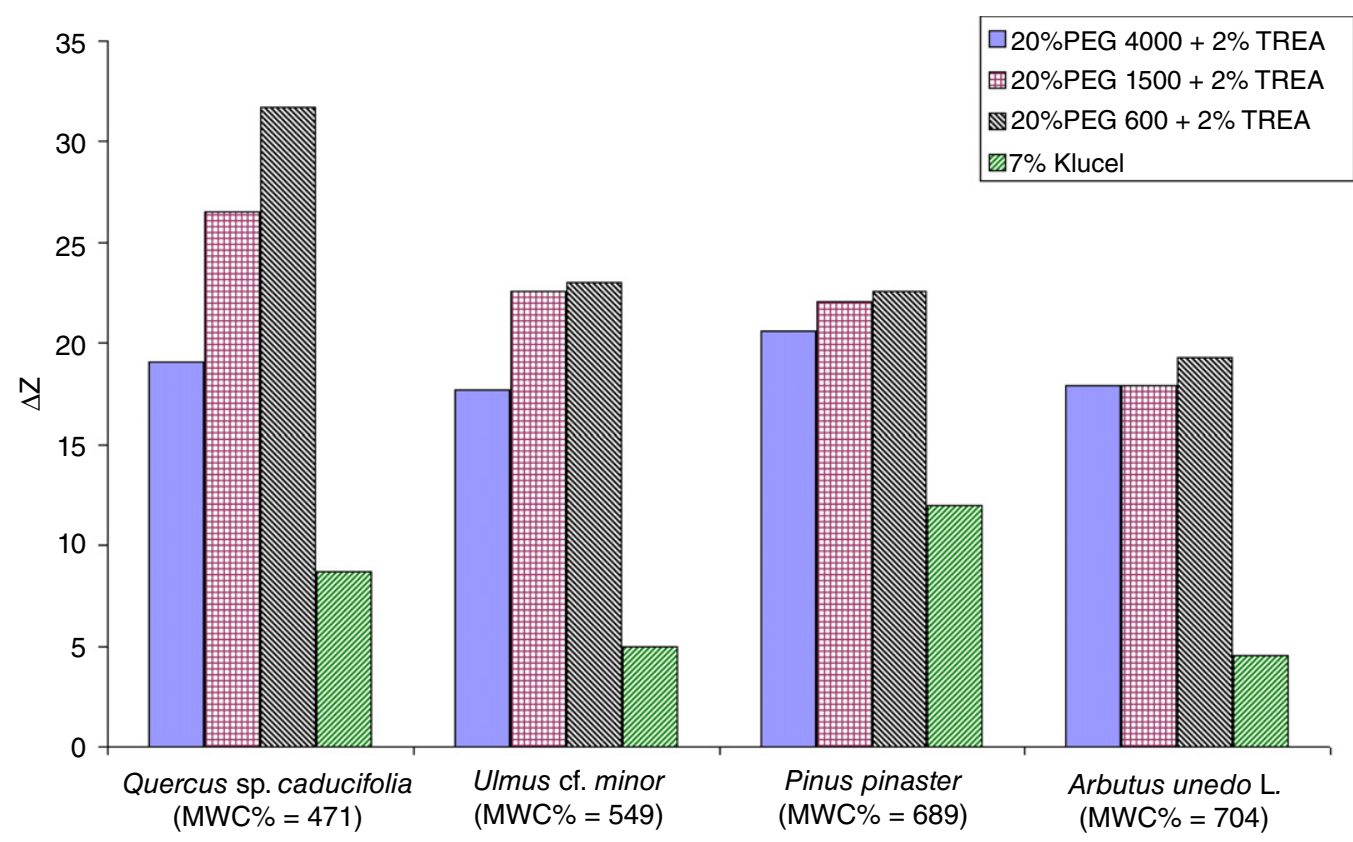

Figure 1 The change in porosity after treatments with aqueous solution of PEG + TREA or Klucel for different wood samples.

Table 4 Comparison of cell-wall densities between woods that are dried, dried from acetone and dried after treatment with different consolidant in acetone solution

\begin{tabular}{|c|c|c|c|c|c|c|}
\hline Taxa & $M W C \%$ & $\begin{array}{c}d_{\text {cell-wall }}, \text { dried } \\
\text { at } 105^{\circ} \mathrm{C} \\
\left(\mathrm{g} \mathrm{cm}^{-3}\right) \\
\sigma \pm 0.01\end{array}$ & $\begin{array}{l}d_{\text {cell-wall }} \text {, dried } \\
\text { from acetone } \\
\quad\left(\mathrm{g} \mathrm{cm}^{-3}\right) \\
\sigma \pm 0.01\end{array}$ & $\begin{array}{c}d_{\text {cell-wall }}{ }^{*}, \text { treated } \\
\text { with colophony } \\
\left(\mathrm{g} \mathrm{cm}^{-3}\right) \\
\sigma \pm 0.01\end{array}$ & $\begin{array}{l}d_{\text {cell-wall }} * \\
\text { treated with } \\
\text { Rosin } 100 \\
\left(\mathrm{~g} \mathrm{~cm}^{-3}\right) \\
\sigma \pm 0.01\end{array}$ & $\begin{array}{c}d_{\text {cell-wall }}{ }^{*}, \\
\text { treated with } \\
8020 \mathrm{~S} \\
\left(\mathrm{~g} \mathrm{~cm}^{-3}\right) \\
\sigma \pm 0.01\end{array}$ \\
\hline $\begin{array}{l}\text { Stone pine, Pinus pinaster } \\
\text { Aiton }\end{array}$ & 559 & 1.38 & 1.46 & 1.23 & 1.18 & 1.37 \\
\hline Elm, Ulmus cf. minor & 479 & 1.41 & 1.46 & 1.23 & 1.19 & 1.34 \\
\hline $\begin{array}{l}\text { European beech, Fagus } \\
\text { sylvatica } \mathrm{L} .\end{array}$ & 676 & 1.37 & 1.40 & 1.21 & 1.18 & 1.32 \\
\hline
\end{tabular}

determination of the volume of the impregnated samples because the flow of He promoted the removal of acetone (high vapour pressure) from the specimen impregnated with the acetone solution of the strengthener, resulting in a continuous variation of the measured volume. Thus, it was not possible to determine $d_{\mathrm{b}}$ and therefore the porosity of the specimen after consolidation.

The $d_{\text {cell-wall }}$ data (Fig. 2), compared at different MWC\% values, showed that the treatment with acetone leads to values of cell-wall density higher than dehydration in the oven at $105^{\circ} \mathrm{C}$. Clearly, a reduction of the volume occupied by the wooden structure has occurred: the highest $d_{\text {cell-wall }}$ value, found for Pinus, could be the result of dissolution in acetone of the resins that, as is well known, are present in softwoods. The consolidation with the Vinavil 8020S yields cell-wall 


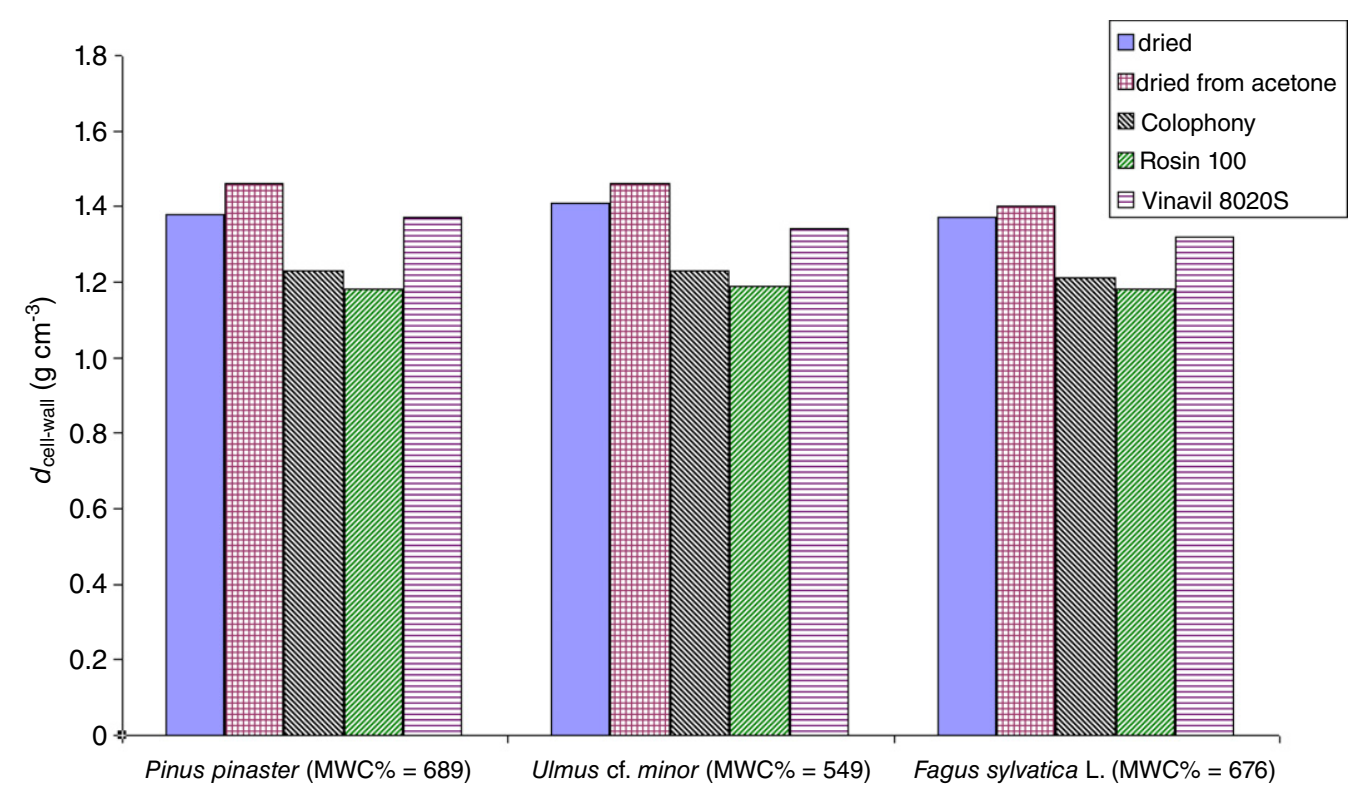

Figure 2 The cell-wall density after treatments for different wood samples.

density values that are slightly smaller than those for acetone, even if their trend with MWC is identical. This may indicate that the consolidating agent essentially affords a film-forming effect. Colophony and modified Rosin (both at $60 \mathrm{wt} \%$ in acetone) lead to a decrease in cell-wall densities associated with an increase of the volume of the cell structure and then to an encrusting effect, which promotes the consolidation. In particular, Rosin 100 seems to be an effective strengthener: the chemical nature, conformation, steric effect and extent of the involved interactions all play a role in the success of the consolidating treatment. This result is in agreement with a recent literature finding (Giachi et al. 2011).

\section{CONCLUSION}

This work was aimed at studying the densities and porosity of wood samples with different taxa and degradation states before and after the treatments with several natural and synthetic consolidants. The cell wall and basic densities of wood samples have been measured. The effects of consolidants for waterlogged wood have been investigated and, in particular, it was found that colophony and modified Rosin lead to an increase in the volume of the cell structure, and then to an encrusting effect, that promotes the consolidation. Measurements carried out on a series of PEGs with different molecular weights showed that the parameters driving the entrance of the strengthener are the taxon, the MWC\% and the consolidant molecular dimensions. Therefore, density and porosity measurements are presented as parameters to give insights into the most efficient consolidant procedure. These measurements could be preliminary to SEM and TEM investigations on the efficiency of the consolidant.

\section{REFERENCES}

Björdal, C. G., and Nilsson, T., 2000, Depth of burial, an important factor in controlling bacterial decay of waterlogged archaeological poles, International Biodeterioration \& Biodegradation, 45, 15-26. 
Björdal, C. G., and Nilsson, T., 2008, Reburial of shipwrecks in marine sediments: a long-term study on wood degradation, Journal of Archaeological Science, 35, 862-72.

Capretti, C., Macchioni, N., Pizzo, B., Galotta, G., Giachi, G., and Giampaola, D., 2008, The characterization of waterlogged archaeological wood: the three roman ships found in Naples (Italy), Archaeometry, 50, 855-76.

Cavallaro, G., Donato, D. I., Lazzara, G., and Milioto, S., 2011a, A comparative thermogravimetric study of waterlogged archaeological and sound woods, Journal of Thermal Analysis and Calorimetry, 104, 451-7.

Cavallaro, G., Donato, D. I., Lazzara, G., and Milioto, S., 2011b, Films of halloysite nanotubes sandwiched between two layers of biopolymer: from the morphology to the dielectric, thermal, transparency, and wettability properties, Journal of Physical Chemistry C, 115, 20491-8.

Colombini, M. P., Lucejko, J. J., Modugno, F., Orlandi, M., Tolppa, E. L., and Zoia, L., 2009, A multi-analytical study of degradation of lignin in archaeological waterlogged wood, Talanta, 80, 61-70.

Donato, D. I., and Agozzino, P., 2004, Composti polimerici per il consolidamento di legni degradati, Science and Technology for Cultural Heritage, 13, 71-81.

Donato, D. I., Lazzara, G., and Milioto, S., 2010, Thermogravimetric analysis: a tool to evaluate the ability of mixtures in consolidating waterlogged archaeological woods, Journal of Thermal Analysis and Calorimetry, 101, 108591.

Eaton, R. A., and Hale, M. D. C., 1993, Wood: decay, pests, and protection, Chapman \& Hall, New York.

Florian, E., 1990, Scope and history of archaeological wood, in Archaeological wood: properties, chemistry, and preservation (eds. R. M. Rowell and R. J. Barbour), American Chemical Society, Washington, DC.

Gallina, M. E., Sassi, P., Paolantoni, M., Morresi, A., and Cataliotti, R. S., 2006, Vibrational analysis of molecular interactions in aqueous glucose solutions, temperature and concentration effects, Journal of Physical Chemistry B, 110, 8856-64.

Giachi, G., Capretti, C., Donato, D. I., Macchioni, N., and Pizzo, B., 2011, New trials in the consolidation of waterlogged archaeological wood with different acetone-carried products, Journal of Archaeological Science, 38, $2957-67$.

Giachi, G., Capretti, C., Macchioni, N., Pizzo, B., and Donato, D. I., 2010, A methodological approach in the evaluation of the efficacy of treatments for the dimensional stabilization of waterlogged archaeological wood, Journal of Cultural Heritage, 11, 91-101.

Italiano, S., 2004, Consolidamento dei reperti lignei provenienti da siti sommersi, Master's thesis, Materiali e tecniche diagnostiche nel settore dei beni culturali.

Jensen, P., and Gregory, D. J., 2006, Selected physical parameters to characterize the state of preservation of archaeological wood: a practical guide for their determination, Journal of Archaeological Science, 33, 551-9.

Maccotta, A., Perzia, P., Donato, D. I., De Maria, M., and Costanzo, E., 2004, Preliminary 1H MRI study on waterlogged wood strengthened with Klucel, in WOAM conference 'The 9 ICOM-CC', Copenhagen, 9, 649-56.

Neimark, A. V., and Ravikovitch, P. I., 1997, Calibration of pore volume in adsorption experiments and theoretical models, Langmuir, 13, 5148-60.

Pfriem, A., Zauer, M., and Wagenführ, A., 2009, Alteration of the pore structure of spruce (Picea abies (L.) Karst.) and maple (Acer pseudoplatanus L.) due to thermal treatment as determined by helium pycnometry and mercury intrusion porosimetry, Holzforschung, 33, 94-8.

Pizzo, B., Giachi, G., and Fiorentino, L., 2010, Evaluation of the applicability of conventional methods for the chemical characterization of waterlogged archaeological wood, Archaeometry, 52, 656-67.

Talu, O., and Myers, A., 2001, Molecular simulation of adsorption: Gibbs dividing surface and comparison with experiment, AIChE Journal, 47, 1160-8.

Tamari, S., 2004, Optimum design of the constant-volume gas pycnometer for determining the volume of solid particles, Measurement Science and Technology, 15, 549-58.

UNI, 2004, UNI 11118:2004, Beni culturali-Manufatti lignei criteri per la identificazione delle specie legnose, archeologiche ed archeobotaniche_Linee guida per la caratterizzazione, UNI, Milan.

UNI, 2007, UNI 11205:2007, Beni culturali_Legno di interesse archeologico ed archeobotanico—Linee guida per la caratterizzazione, UNI, Milan.

Weber, J., and Bastick, M., 1968, Influence de la température sur la détermination de la masse volumique de divers carbones par pycnométrie dans l'helium, Bulletin de la Société Chimique de France, 7, 2702-6. 